\title{
PENGEMBANGAN BAHAN AJAR MATEMATIKA SD BERBASIS MODEL PEMBELAJARAN REALISTIC MATHEMATICS EDUCATIONYANG BERORIENTASI KEMAMPUAN BERPIKIR KRITIS
}

\author{
Ujiati Cahyaningsih, Dede Salim Nahdi \\ Universitas Majalengka, Indonesia \\ ujiati@unma.ac.id
}

\begin{abstract}
Critical thinking is a skill that is needed to be able to compete in the 21 st century. Therefore, it is very important that this skill be instilled in children as early as possible. However, this skill has not been fully developed in children. This is revealed from several studies that show the critical thinking skills of elementary school students are still low. Efforts that teachers can make are to develop teaching materials that can facilitate increased critical thinking and are supported by appropriate learning models. On this basis, the authors conducted research on the development of mathematics teaching materials for elementary school students. The purpose of this research is to produce valid, practical and effective mathematics teaching materials. The development research model used is the Plomp model which consists of five development phases, namely (1) the initial investigation phase, (2) the design phase, (3) the realization phase, (4) the test, evaluation and revision phases, and (5) implementation phase. The results showed that the teaching materials developed met the valid, practical and effective criteria.
\end{abstract}

Keywords: development of teaching materials, realistic mathematic education, critical thinking

\begin{abstract}
ABSTRAK
Berpikir kritis merupakan keterampilan yang dibutuhkan agar mampu bersaing di abad 21. Oleh karena itulah, sangat penting keterampilan ini ditanamkan pada anak sedini mungkin. Namun keterampilan ini belum sepenuhnya dikembangkan pada anak. Hal ini terungkap dari beberapa studi yang menunjukkan keterampilan berpikir kritis siswa sekolah dasar masih rendah. Upaya yang dapat dilakukan guru adalah dengan mengembangkan bahan ajar yang dapat memfasilitasi peningkatan berpikir kritis serta ditunjang dengan model pembelajaran yang tepat. Atas dasar itulah penulis melakukan penelitian pengembangan bahan ajar matematika untuk siswa sekolah dasar. Tujuan dari penelitian ini adalah menghasil bahan ajar matematika yang valid, praktis dan efektif. Model penelitian pengembangan yang digunakan yaitu model Plomp yang terdiri dari lima fase pengembangan, yaitu (1) fase investigasi awal, (2) fase desain, (3) fase realisasi, (4) fase tes, evaluasi, dan revisi, dan (5) fase implemestasi. Hasil penelitian menunjukkan bahan ajar yang dikembangkan memenuhi kriteria valid, praktis dan efektif.

Kata Kunci: pengembangan bahan ajar, realistic mathematic education, berpikir kritis
\end{abstract}

Submitted Nov 16, 2020 | Revised Nov 27, 2020 | Accepted Des 04, 2020

\section{Pendahuluan}

Matematika merupakan salah satu mata pelajaran wajib di sekolah yang memiliki peran penting dalam kehidupan manusia (Nahdi, et al., 2020). Matematika sekolah memiliki tujuan salah satunya memberikan bekal kemampuan berpikir kritis pada siswanya. Berpikir kritis merupakan salah satu keterampilan yang dibutuhkan untuk hidup di abad 21 (Sunardi, et al., 2017; Nahdi, 2019; Redhana, 2019). Beberapa akademisi dalam studinya telah membahas begitu pentingnya keterampilan berpikir kritis dalam konteks pendidikan dan tenaga kerja abad ke-21 (Geertsen, 2003; Barrington, et al., 2006). Keterampilan berpikir kritis secara berkesinambungan dimasukkan dalam aspek penting dalam persiapan memasuki jenjang kuliah dan karier (Costa \& Kallick, 2014; Kraisuth \& Panjakajornsak, 2017). Untuk mampu bekerja dan berkarir di era masyarakat ekonomi global, siswa harus sedini mungkin diajarkan keterampilan berpikir kritis (Changwong, et al., 2018); Amalia, et al., 2019).

Keterampilan berpikir kritis dapat dikembangkan melalui pembelajaran dan penilaian di kelas (Widana, et al., 2018). Dalam pembelajaran matematika di sekolah, berpikir kritis perlu diintegrasikan 
dan ditekankan dalam kurikulum sehingga siswa dapat mempelajari dan menerapkannya untuk peningkatan kinerja dan kemampuan bernalar (Chukwuyenum, 2013). Hal ini karena, dalam melaksanakan pembelajaran yang bermakna, kemampuan berpikir kritis tidak dapat dipisahkan dari matematika (Innabi \& Sheikh, 2006; Aizikovitsh \& Amit, 2010). Berpikir kritis dalam belajar matematika merupakan suatu proses kognitif atau tindakan mental dalam usaha memperoleh pengetahuan matematika berdasarkan penalaran matematika (Supardi, 2012; Paradesa, 2015; Abdullah, 2016). Berpikir kritis merupakan seni untuk meningkatkan keterampilan berpikir dalam menganalisis dan mengevaluasi pemecahan masalah tertentu (Paul \& Elder, 2006). Berpikir kritis akan membuat siswa terampil dapat menyelesaikan masalah sederhana hingga kompleks baik dalam pelajaran maupun di kehidupan sehari-hari (Snyder \& Snyder, 2008: Gunn, Grigg, \& Pomahac, 2008). Karenanya, mengembangkan kemampuan berpikir kritis harus menjadi tujuan dalam pembelajaran matematika (Jacob, 2012; Purwati, Hobri, \& Fatahillah, 2016).

Pentingnya berpikir kritis dimiliki siswa menjadikan keterampilan ini harus menjadi perhatian bagi setiap guru dalam melaksanakan pembelajaran matematika, termasuk di sekolah dasar. Setiap aktivitas pembelajaran yang dilakukan haruslah berdasarkan pada tujuan meningkatkan keterampilan berpikir siswa. Namun beberapa hasil studi mengungkap bahwa keterampilan berpikir siswa sekolah dasar masih rendah dan diperlukan berbagai upaya untuk meningkatkannya (Anjarwati, 2016; Umam, 2018; Suci, Firman, \& Neviyarni, 2019; Lisbiyaningrum, Wulandari, \& Wahyudi, 2019).

Rendahnya keterampilan berpikir kritis siswa menunjukkan ada hal yang belum optimal dalam pembelajaran matematika yang dirancang guru. Salah satu upaya yang dapat dilakukan guru adalah melalui pengelolan pelaksanaan pembelajaran. Mengembangkan bahan ajar matematika dengan model pembelajaran yang tepat merupakan salah satu cara yang dapat diupayakan guru (Nahdi dan Cahyaningsih, 2018). Bahan ajar merupakan seperangkat media atau alat pembelajaran yang di dalamnya berisi tentang materi, metode, batasan-batasan dan cara melakukan evaluasi yang dirancang secara sistematis dan menarik untuk mencapai tujuan yang dinginkan, yaitu tercapainya kompetensi serta sub-kompetensi dengan berbagai kompleksitasnya (Chomsin dan Jasmadi, 2008; Miftah, 2013).

Untuk memperoleh hasil yang optimal dalam meningkatkan keterampilan berpikir kritis, selain mengembangkan bahan ajar, pemilihan model atau pendekatan pembelajaran yang tepat dengan materi ajar juga perlu dilakukan. Hal ini karena penerapan metode atau pendekatan pembelajaran yang digunakan akan berdampak pada pencapaian kompetensi siswa yang diharapkan. Kemampuan yang diharapkan dimiliki siswa akan ditentukan oleh kesesuaian penggunaan suatu metode atau pendekatan pembelajaran yang sesuai dengan tujuan (Djamarah \& Zain, 2006). Salah satu model pembelajaran yang dapat memfasilitasi keterampilan berpikir kritis adalah Realistic Mathematic Education (RME). Hal ini atas dasar bahwa dalam melaksanakan pembelajaran matematika, guru harus memulainya dengan pengenalan situasi atau masalah kontekstual (Habsah, 2014). Siswa akan mudah mempelajari matematika jika isi dan konteks pembelajaran dikaitkan dengan aktivitas sehari-hari (Laurens, et al., 2018). Realistic Mathematic Education (RME) merupakan salah satu pendekatan yang menggunakan masalah kontekstual sebagai titik awal pembelajaran matematika (Shanty, 2011; Palinussa, 2013). RME mampu menyelesaikan masalah pembelajaran matematika yang dipandang tradisional dan abstrak (Bray \& Tangney, 2015). RME memandang matematika sebagai aktivitas manusia yang terhubung dengan kenyataan (Makonye, 2014). RME memberikan kesempatan bagi siswa untuk menemukan kembali ide dan konsep matematika dengan bimbingan guru dengan menjelajah berbagai situasi dan masalah dunia nyata (Ulandari, Amry, \& Saragih, 2019).

Beberapa penelitian terkait sebelumnya telah mengungkapkan manfaat RME dalam pembelajaran matematika. Studi-studi juga telah mengungkap hubungan antara berpikir kritis yang dihasilkan dari model atau strategi pembelajaran tersebut. Lady, Utomo, \& Chikita, (2018) telah menguji pengaruh RME terhadap kemampuan matematika dan hasil belajar. Penelitian Nurhayati \& Hartono (2017) telah mengungkap fakta bahwa pemahaman konsep siswa SMP yang terlibat dalam pembelajaran kooperatif 
tipe STAD yang dikombinasikan dengan RME lebih baik dibanding siswa di kelas reguler. Dhayanti, Johar, \& Zubainur (2018) berhasil meningkatkan kemampuan berpikir kritis dan kreatif siswa sekolah menengah dengan menerapkan RME dalam pembelajaran matematika. Dari beberapa hasil penelitian tersebut menunjukkan bahwa RME dapat diterapkan secara efektif untuk meningkatkan prestasi kognitif dan beberapa keterampilan matematis.

Penelitian ini bertujuan untuk menghasilkan bahan ajar matematika yang berbasis model RME untuk meningkatkan kemampuan berpikir kritis siswa. Urgensi dari penelitian ini adalah penekanannya pada kebutuhan bahan ajar matematika yang dapat membangun keterampilan berpikir kritis matematika. Terlepas dari kenyataan bahwa matematika sering dipandang sebagai ilmu abstrak yang sulit dipahami siswa sekolah dasar. Penggunaan RME di kelas dapat memberikan contoh bagi siswa berdasarkan kegiatan sehari-hari mereka untuk membantu dalam memecahkan masalah serta kesulitan siswa.

\section{Metode Penelitian}

Penelitian ini adalah penelitian pengembangan yang mengacu pada model pengembangan Plomp. Menurut Rochmad (2012) model ini terdiri dari lima fase pengembangan, yaitu (1) fase investigasi awal, (2) fase desain, (3) fase realisasi, (4) fase tes, evaluasi, dan revisi, dan (5) fase implemestasi. Fase investigasi awal dilakukan untuk menentukan masalah dasar yang diperlukan dalam pengembangan bahan ajar dengan pendekatan RME untuk meningkatkan kemampuan berpikir kritis siswa. Pada fase ini dilakukan analisis kurikulum, analisis siswa, dan analisis materi ajar. Fase desain bertujuan untuk merancang atau mendesain bahan ajar beserta instrumen-instrumen penelitian yang dibutuhkan. Rancangan perangkat dan instrumen penelitian pada fase ini berdasarkan hasil fase investigasi awal. Fase realisasi merupakan tindak lanjut dari fase desain. Pada fase ini dilakukan pembuatan bahan ajar dan instrumen-instrumen yang dibutuhkan. Hasil dari fase realisasi adalah bahan ajar dengan pendekatan RME untuk meningkatkan kemampuan berpikir kritis siswa. Bahan ajar hasil dari fase ini adalah prototipe I. Pada fase tes, evaluasi, dan revisi ada dua kegiatan utama yang dilakukan, yaitu validasi bahan ajar pada para ahli dan uji coba bahan ajar. Hasil dari fase uji coba terbatas berupa data penelitian dan bahan ajar. Selanjutnya, data penelitian yang diperoleh akan dianalisis untuk mengetahui keefektifan bahan ajar sehingga menghasilkan laporan penelitian dan bahan ajar akan direvisi sehingga menghasilkan prototipe final.

\section{Hasil dan Pembahasan}

Bahan ajar matematika pada penelitian ini disusun dan dikembangkan berdasarkan model Plomp yang terdiri dari lima tahap yaitu tahap pengkajian awal (preliminary investigation phase), tahap perancangan (design phase), tahap realisasi/konstruksi (realization/construkction phase), tahap tes, evaluasi, dan revisi (test, evaluation, and revision phase), dan tahap implementasi (implementation).

Pada tahap pengkajian awal ditemukan bahwa, Kurikulum yang digunakan di sekolah adalah Kurikulum 2013, tetapi guru masih menggunakan pola pengajaran yang tidak sesuai dengan pendekatan yang lebih ditekankan dikurikulum 2013. Pada tahap analisis peserta didik diketahui bahwa pengetahuan matematika dan kemampuan berpikir kritis peserta didik masih rendah khususnya pada materi bangun datar dan bangun ruang. Penulis juga melihat model pembelajaran yang digunakan oleh guru adalah model pembelajaran yang konvensional, artinya pembelajaran berpusat pada guru, siswa hanya mendengar penjelasan guru melalu proyektor yang terpasang sehingga siswa kurang antusias untuk belajar, akibatnya siswa kurang memahami konsep materi yang diajarkan. Setelah melakukan telaah literatur untuk mengkaji teori-teori yang cocok untuk digunakan, penulis mendapat sebuah model pembelajaran yang sesuai dengan kurikulum 2013 dan juga dapat membuat siswa lebih mandiri dan lebih aktif menemukan konsep dari materi yang dipelajarinya. Model pembelajaran tersebut adalah 
Realistic Mathematic Education. Kemudian pada analisis materi, materi yang di pilih dalam penelitian ini adalah materi bangun datar dan bangun ruang, untuk mengembangkan kemampuan berpikir kritis siswa dengan pendekatan RME, maka materi bangun datar dan bangun ruang sangat tepat karena dalam materi tersebut banyak mengandung penerapan pada dunia nyata.

Pada fase perancangan, peneliti merancang design dan sistmatika bahan ajar yang dirancang disesuaikan dengan model pendekatan RME dengan materi bangun datar dan bangun ruang. Bahan ajar ini disusun dengan mengacu pada kompetensi dasar dan indikator. Pengembangan bahan ajar ini menggunakan 3 instrumen penelitian yaitu kevalidan, kepraktisan dan keefektifan. Selanjutnya dihasilkan prototype1 bahan ajar matematika berbasis RME yang kemudian kita uji kevalidan kepada validator. kriteria hasil keterlaksanaan bahan ajar dikatakan tidak reliabel karena nilai reliabilitasnya $(\mathrm{R})$ $\leq 0,75$ yaitu 0,71. Jadi, dapat dikatakan bahwa bahan ajar belum valid atau belum bisa digunakan. Karena uji reliabilitas yang pertama belum valid, maka dilakukan revisi serta dilakukan uji validitas dan reliabilitas kembali.

Tabel 1. Hasil validasi ke 2

\begin{tabular}{cccc}
\hline No & \multicolumn{1}{c}{ Uraian } & $\mathrm{A}_{1}$ & Keterangan \\
\hline 1 & Format Bahan Ajar & 3,4 & Valid \\
2 & Isi Bahan Ajar & 2,9 & Valid \\
3 & Bahasa & 3,2 & Valid \\
Kesimpulan & (R) 0,93 & Valid \\
\hline
\end{tabular}

Pada validasi kedua nilai reliabilitasnya $(\mathrm{R}) \geq 0,75$ yaitu 0,93 sehingga dapat di katakan bahwa bahan ajar sudah valid. Selanjutnya di lakukan tes kepraktisan dan keefektifan dan hasilnya bahan ajar yang di kembangkan sudah praktis dan efektif.

Kemudian pada tahap implementasi, setelah bahan ajar matematika berbasis RME pada pokok bahasan bangun datar dan bangun ruang dikembangkan dan dinyatakan valid serta hasil uji coba terbatas dan lapangan memenuhi syarat kelayakan, dapat disimpulkan bahwa bahan ajar matematika berbasis RME yang dikembangkan praktis dan efektif digunakan untuk mengembangkan kemampuan berpikir kritis peserta didik.

\section{Kesimpulan}

Dalam penelitian ini, perangkat pembelajaran dikatakan layak jika telah memenuhi 3 syarat kelayakan yaitu valid, praktis, dan efektif. Ditinjau dari segi kevalidan, berdasarkan hasil validasi bahan ajar diperoleh data bahwa hasil validasi terbagi atas dua tahap yaitu tahap validasi I dan tahap validasi II. Pada tahap validasi I, bahan ajar dikatakan belum valid dan belum layak digunakan. Pada tahap II semua saran-saran para validator telah diperbaiki dan dikatakan valid serta layak digunakan.

Ditinjau dari segi kepraktisan, berdasarkan hasil uji coba kepraktisan diperoleh bahwa hasil keterlaksanaan bahan ajar dinilai telah valid sehingga praktis untuk digunakan. Sedangkan dari segi keefektifan, berdasarkan data hasil uji coba keefektifan diperoleh data bahwa: (1) rata-rata ketuntasan belajar peserta didik yang diperoleh adalah $85 \%$. (2) lima dari enam jenis aktivitas peserta didik yang diamati telah terpenuhi. Dan (3) rata-rata skor kemampuan guru dalam pengelolaan pembelajaran adalah 3,4 dari skor ideal 4 (berada dalam kategori cukup/sedang). Sehingga dapat disimpulkan bahwa perangkat pembelajaran efektif untuk digunakan.

\section{Daftar Pustaka}

Abdullah, I. H. (2016). Berpikir kritis matematik. Delta-Pi: Jurnal Matematika dan Pendidikan Matematika, 2(1), 66-75. http://ejournal.unkhair.ac.id/index.php/deltapi/article/view/100

Aizikovitsh, E. \&Amit, M. (2010). Evaluating an infusion approach to the teaching of critical thinking skills through mathematics. Procedia Social and Behavioral Sciences, 2 (1), 3818-3822. https://doi.org/10.1016/j.sbspro.2010.03.596 
Amalia, N., Subanji, S., \& Untari, S. (2019). Kemampuan Berpikir Kritis Siswa Melalui Penerapan Pendekatan Realistic Mathematics Education Berbantuan Media Manipulatif Origami. Jurnal Pendidikan: Teori, Penelitian, dan Pengembangan, 4(8), 1084-1091. doi:http://dx.doi.org/10.17977/jptpp.v4i8.12681

Anjarwati, Y. (2016). Peningkatan Keterampilan Berpikir Kritis pada Pembelajaran Geometri dengan Pendekatan Pendidikan Matematika Realistik dikelas IV SDN 1 Pule Kecamatan Pule Kabupaten Trenggalek. Jurnal Kajian Pendidikan dan Hasil Penelitian, 2(1), 99. http://dx.doi.org/10.26740/jrpd.v2n1.p98-104

Barrington, L., Casner-Lotto, J., \& Wright, M. (2006). Are they really ready to work? Employers' perspectives on the basic knowledge and applied skills of new entrants to the 21st Century U.S. workforce. The Partnership for 21st Century Skills. Retrieved from http://tinyurl.com/j2c5uh6.

Bray, A. \& Tangney, B. (2015). Enhancing student engagement through the affordances of mobile technology: A 21st century learning perspective on realistic mathematics education. Mathematics Education Research Journal. doi.org/10.1007/s13394-015-0158-7.

Changwong, K., Sukkamart, A., \& Sisan, B. (2018). Critical thinking skill development: Analysis of a new learning management model for Thai high schools. Journal of International Studies, 11(2), 3748. doi: https://doi.org/10.14254/20718330.2018/11-2/3

Chukwuyenum, A.N. (2013). Impact of Critical thinking on Performance in Mathematics among Senior Secondary School Students in Lagos State. IOSR Journal of Research \& Method in Education, 3, 18-25. https://doi.org/10.9790/7388-0351825.

Costa, A. \& Kallick. B. (2014). Dispositions: Reframing teaching and learning. Thousand Oaks, CA: Corwin Press.

Djamarah, S. B. \& Zain, A. (2006). Strategi Belajar Mengajar. Rieneka Cipta: Jakarta.

Dhayanti, D., Johar, R., \& Zubainur, C. (2018). Improving Students' Critical and Creative Thinking through Realistic Mathematics Education using Geometer's Sketchpad. JRAMathEdu Journal of Research and Advances in Mathematics Education), 3(1), 25-35. doi:https://doi.org/10.23917/jramathedu.v3i1.5618

Geertsen, H. R. (2003). Rethinking thinking about higher-level thinking. Teaching Sociology, 1-19. doi.org/10.2307/3211421

Habsah, F. (2017). Developing teaching material based on realistic mathematics andoriented to the mathematical reasoning and mathematical communication. Jurnal Riset Pendidikan Matematika, 4(1), 43-55. doi:https://doi.org/10.21831/jrpm.v4i1.10199

Innabi, H., \& El Sheikh, O. (2007). The change in mathematics teachers' perceptions of critical thinking after 15 years of educational reform in Jordan. Educational Studies in Mathematics, 64(1), 45-68. https:// doi.org/10.1007/s10649-005-9017-x

Jacob, S. M. (2012). Mathematical achievement and critical thinking skills in asynchronous discussion forums. Procedia-Social and Behavioral Sciences, 31, 800-804.

Kraisuth, D., \& Panjakajornsak, V. (2017). Thai engineer ASEAN readiness: A structural equation model analysis. Asia-Pacific Social Science Review, 16(3), 96-117. https://doi.org/10.1177/2158244017745346

Lady, A., Utomo, B., \& Chikita, L. (2018). Improving mathematical ability and student learning outcomes through realistic mathematic education (RME) approach. International Journal of Engineering \& Technology, 7(2.10), 55-57. doi:http://dx.doi.org/10.14419/ijet.v7i2.10.10954

Laurens, T., Batlolona, F. A., Batlolona, J. R., \& Leasa, M. (2018). How Does Realistic Mathematics Education (RME) Improve Students' Mathematics Cognitive Achievement?. Eurasia Journal of Mathematics, Science and Technology Education, 14(2), 569-578. https://doi.org/10.12973/ejmste/76959 
Lisbiyaningrum, I., Wulandari, Wahyudi. (2019). Penerapan Problem Based Learning Dalam Pembelajaran Tematik Integratif Untuk Meningkatkan Kemampuan Berpikir Kritis Siswa Kelas III Sekolah Dasar. Elementary School, https://journal.upy.ac.id/index.php/es/article/view/276

Makonye, J. P. (2014). Teaching functions using a realistic mathematics education approach: A theoretical perspective. International Journal of Educational Sciences, 7(3), 653-662.

Miftah, M. (2013). Fungsi, Dan Peran Media Pembelajaran Sebagai Upaya Peningkatan Kemampuan Belajar Siswa. Kwangsan, 1(2).

Nahdi, D. S., \& Cahyaningsih, U. (2018). Pengembangan Perangkat Pembelajaran Matematika Sd Kelas V dengan Berbasis Pendekatan Saintifik Yang Berorientasi Pada Kemampuan Pemecahan Masalah Siswa. Jurnal Cakrawala Pendas, 5(1).

Nahdi, D., S. (2019). Keterampilan Matematika Di Abad 21. Jurnal Cakrawala Pendas, 5(2). doi:http://dx.doi.org/10.31949/jcp.v5i2.1386

Nahdi, D., Jatisunda, M., Cahyaningsih, U., \& Suciawati, V. (2020). Pre-service Teacher's Ability In Solving Mathematics Problem Viewed From Numeracy Literacy Skills. Elementary Education Online, 19(4), 1902-1910. Retrieved from http://ilkogretimonline.org.tr/index.php/io/article/view/4094/2810

Nurhayati, D. M., \& Hartono. (2017). Implementation of cooperative learning model type STAD with RME approach to understanding of mathematical concept student state junior high school in Pekanbaru. AIP Conference Proceedings 1848, 040002. doi: https://doi.org/10.1063/1.4983940.

Palinussa, A. L. (2013). Students' Critical Mathematical Thinking Skills and Character: Experiments for Junior High School Students through Realistic Mathematics Education Culture-Based. Indonesian Mathematical Society Journal on Mathematics Education, 4(1), 75-94. DOI: https://doi.org/10.22342/jme.4.1.566.75-94

Paradesa, R. (2015). Kemampuan Berpikir Kritis Matematis Mahasiswa Melalui Pendekatan Konstruktivisme Pada Matakuliah Matematika Keuangan. Jurnal Pendidikan Matematika RAFA, $1(2), 306-325$.

Paul, R., \& Elder, L. (2001). The miniature guide to critical thinking: Concepts \& tools. Foundation Critical Thinking.

Purwati, R., Hobri, H., \& Fatahillah, A. (2016). Analisis Kemampuan Berpikir Kritis Siswa Dalam Menyelesaikan Masalah Persamaan Kuadrat Pada Pembelajaran model Creative Problem Solving. KadikmA, 7(1), 84-93. from https://jurnal.unej.ac.id/index.php/kadikma/article/view/5471

Redhana, I. (2019). Mengembangkan Keterampilan Abad Ke-21 Dalam Pembelajaran Kimia. Jurnal Inovasi Pendidikan Kimia, 13(1). Retrieved from https://journal.unnes.ac.id/nju/index.php/JIPK/article/view/17824

Rochmad, R. (2012). Desain Model Pengembangan Perangkat Pembelajaran Matematika. Kreano, Jurnal Matematika Kreatif-Inovatif, 3(1), 59-72.

Shanty, N. O. (2011). Design research on mathematics education: investigating the progress of Indonesian fifth grade students' learning on multiplication of fractions with natural numbers. Journal on Mathematics Education (JME), 2(02), 147-162. DOI: https://doi.org/10.22342/jme.2.2.749.147-162

Snyder, L. G., \& Snyder, M. J. (2008). Teaching Critical Thinking and Problem Solving Skills. The Journal of Research in Business Education, 50(2), 90-99. https://eric.ed.gov/?id=EJ826495

Suci, D.W. Firman, Neviyarni. (2019). Peningkatan Keterampilan Berpikir Kritis Siswa Melalui Pendekatan Realistik di Sekolah Dasar. Jurnal Basicedu, 3(4), 2042-2049. https://doi.org/10.31004/basicedu.v3i4.229 
Sulaiman, W. S. W., Rahman, W. R. A., \& Dzulkifli, M. A. (2008). Relationship between Critical Thinking Dispositions, Perceptions towards Teacher, Learning Approaches and Critical Thinking Skills among University Students. The Journal of Behavioral Science, 3(1), 122-133. Retrieved from https://so06.tci-thaijo.org/index.php/IJBS/article/view/2169

Sunardi, S., Kurniati, D., Sugiarti, T., Yudianto, E., \& Nurmaharani, R. (2017). Pengembangan Indikator 4c's yang Selaras dengan Kurikulum 2013 pada Mata Pelajaran Matematika SMA/MA Kelas X Semester 1. AdMatbEdu : Jurnal Ilmiah Pendidikan Matematika, Imu Matematika dan Matematika Terapan, 7(2), 197-210. DOI: http://dx.doi.org/10.12928/admathedu.v7i2.9159

Supardi, U.S. (2012). Peran berpikir kreatif dalam proses pembelajaran matematika. Jurnal Formatif, 2 (3).

Taubah, R., Isnarto, I., \& Rochmad, R. (2018). Student Critical Thinking Viewed from Mathematical Self-efficacy in Means Ends Analysis Learning with the Realistic Mathematics Education Approach. Unnes Journal of Mathematics Education Research, 7(1), 189-195. Retrieved from https://journal.unnes.ac.id/sju/index.php/ujmer/article/view/25562

Ulandari, L., Amry, Z., \& Saragih, S. (2019). Development of Learning Materials Based on Realistic Mathematics Education Approach to Improve Students' Mathematical Problem Solving Ability and Self-Efficacy. International Electronic Journal of Mathematics Education, 14(2), 375-383. https://doi.org/10.29333/iejme/5721

Umam, K. (2018). Peningkatan Kemampuan Berpikir Kritis Matematis Siswa Melalui Pembelajaran Reciprocal Teaching. JPMI (Jurnal Pendidikan Matematika Indonesia), 3(2), 57-61. http://dx.doi.org/10.26737/jpmi.v3i2.807

Widana, I. W., Parwata, I. M. Y., Parmithi, N. N., Jayantika, I. G. A. T., Sukendra, K., \& Sumandya, I. W. (2018). Higher order thinking skills assessment towards critical thinking on mathematics lesson. International Journal of Social Sciences and Humanities, 2(1), 24-32. https://doi.org/10.29332/ijssh.v2n1.74 